\title{
KINETICS OF DEHYDRATION OF AROIDS AND DEVELOPED DEHYDRATED AROIDS PRODUCTS
}

\author{
M. Kamruzzaman* and M.N. Islam \\ Department of Food Technology and Rural Industries, \\ Bangladesh Agricultural University, Mymensingh, Bangladesh
}

\begin{abstract}
The study was concerned with the dehydration kinetics of aroids in mechanical dryer at different drying condition such as variable air dry bulb temperature and air velocity. Fresh aroids with 3, $5 \mathrm{~mm}$ slice and 8 mm cube were used as raw materials for drying. The experimental results showed that drying rate constant and thickness can be expressed as power law equation. The exponent of the equation for aroids was 1.15 indicating presence of significance external mass transfer resistance. Increasing loading density gave decreased drying rate constant and when air velocity of dryer was increased, drying rate constant was also increased, as higher air velocity reduces the external resistance to mass transfer and also higher temperature gave faster drying rate. The activation energy of diffusion of water from aroids during drying as per Arrhenius equation was found to be $5.12 \mathrm{k}$ cal $/ \mathrm{g}$-mole. The chemical compositions of fresh and dried aroids were determined and it was observed that all the constituent remained almost constant, only fat decreased slightly possibly due to oxidation. Organoleptic taste testing showed that "chapatti" prepared from aroids powder (aroids powder: wheat flour =1:4) were adjudged to be the best by the panelists using 1-9 hedonic scale and ranked as like moderately securing score 7.3.
\end{abstract}

\section{Introduction}

Aroids (Colocasia esculenta) locally known as "kachu" is a tropical tuber crop cultivated in Bangladesh for its leaves, corms and cormels. Different types and sizes of aroids are grown in Bangladesh and mainly cultivated in greater Mymensingh. From the economic point of view, the aroids are important root crops for most of the tropical developing and some of the developed countries. Flour made from aroids is an excellent starchy food and was prescribed to cereal allergy sufferers ${ }^{8}$. Chowdhury ${ }^{5}$ reported that the nutritive value of corms of aroids seems to be comparable with that of the other starchy foods. Notwithstanding their high starch content, edible aroids have a higher content of protein and amino acids than many other tropical root crops $^{14}$. Protein quality is essentially the same for all aroids determined with lysine as first limiting amino acid $^{4}$.

A comparative chemical analysis per $100 \mathrm{~g}$ of rice, potato and corms of two of the aroids indicates that besides being comparable in respect of some nutrient contents, the corms seem to be richer in $\mathrm{Ca}$ and $\mathrm{Fe}^{16}$. Flour made from aroids is an excellent starchy food and is highly digestible due to small grain size ${ }^{6}$. According to Gerpacio et al. ${ }^{7}$ the advantage of using aroids for preparing infant food is that it contains an appreciable amount of protein and it does not contain hydrocyanic acid or any toxic substance in amount which is generally found in case of cassava. Its higher digestibility is an added advantage for its suitability for this purpose. Converting tubers into flours and starches may be an important process that could contribute to minimizing losses and to allow the commercial food industry to store the tuber throughout the year by using appropriate drying technology. Preservation by drying of this vegetable can prevent the wastage and make them available in the off-season. Processing of this vegetable into shelfstable products using efficient drying procedure and effective utilization of the finished products will enhance availability of the vegetable throughout the year. Moreover, this will stimulate increased production, bring better returns to the farmers and improve nutritional status of the people. Drying can be accomplished in a mechanical dryer, direct sunlight or solar dryer. In the mechanical dryer, desired temperature and airflow could be maintained. Compared to sun/solar drying higher airflow and temperature can be used in mechanical drying. As a result higher production rates and improved quality products are achieved. Moreover mechanical drying is being independent of sunlight it can be done as and when necessary.

So the objective of this work was to study the dehydration kinetics of aroids using mechanical dryer and develop aroids flour that could be used as a supplementary raw material for the production of "chapatti" and to assess the overall acceptability of the developed products. 


\section{Materials and methods}

Fresh aroids grown in Mymensingh were used for drying process to develop dried aroids slices and aroids powder. Aroids were sliced into desired thickness and placed in trays as to form a single layer and drying commenced in dryer. Weight loss was used as a measure of extent of drying. Initial moisture content was determined as per method of Ranganna ${ }^{17}$. AOAC $^{2}$ methods were used to determine crude fat and protein content of the aroids.

\section{Experimental Apparatus}

Forced convection hot air type cabinet dryer (Figure 1) was used for drying of aroids.

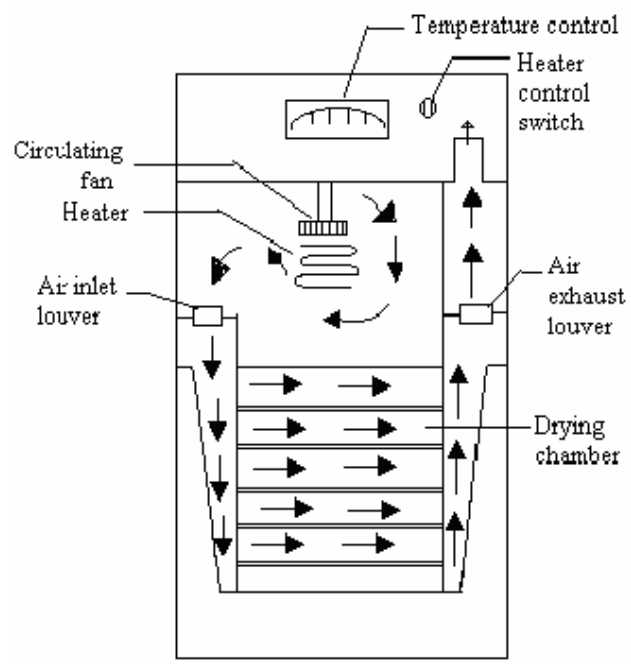

Fig 1. Schematic diagram of forced convection hot air type cabinet dryer

The dryer consisted of an insulated cabinet containing a circulating fan, which was fixed over the heating element (heater) and above the cabinet chamber. When the equipment was run, the circulating fan drew air through the heater and this heated air was forced to the chamber through the adjustable louvers at the inlet port. This heated air then passed into the chamber and over the product which was placed on trays. The heated air, having less moisture content, picked up moisture from the exposed food materials placed on the trays and having a higher moisture content. The moist air then left the chamber and went out through exhaust port. The exhaust air was controlled by an adjustable louver at the outlet port. The velocity of air was measured (0.6 and $1.25 \mathrm{~m} / \mathrm{sec}$.) by an Anemometer.

\section{Characteristics dimensions of dryer:}

Size $=2 \mathrm{mx} 1 \mathrm{mx} 0.84 \mathrm{~m}$

Chamber size $=1 \mathrm{mx} 0.64 \mathrm{mx} 0.66 \mathrm{~m}$

Temperature range $=38^{\circ} \mathrm{C}$ to $340^{\circ} \mathrm{C}$

\section{Analysis of experimental data}

Since food dehydration is most frequently assumed to take place by diffusion process, Fick's second law of diffusion can be applied for describing mass transfer during drying. The expression is

$\frac{\delta M}{\delta t}=\nabla^{2} D_{e} M$

Where, $\mathrm{M}=$ Moisture content

$\mathrm{T}=$ Time

$\mathrm{D}_{\mathrm{e}}=$ Effective diffusion co-efficient

The solution of the above unsteady state diffusion equation for one dimensional transport for the case of initial uniform moisture distribution in the sample was derived by Brooker et.al ${ }^{3}$ and Islam $^{12}$ when dried from one major face is:

$$
\begin{aligned}
& \mathrm{MR}=\frac{M_{t}-M_{e}}{M_{o}-M_{e}}=\frac{8}{\pi^{2}}=\frac{8}{\pi_{n=0}} \frac{1}{(2 n+1)^{2}} \operatorname{Exp} \\
& {\left[\frac{-(2 n+1)^{2} \pi^{2} D_{e} t}{L^{2}}\right] \text {---- (1) }}
\end{aligned}
$$

For low $\mathrm{M}_{\mathrm{e}}$ values and for moisture ratio (MR) less than six, equation (1) reduces to,

$$
\frac{M_{t}}{M_{o}}=\frac{8}{\pi^{2}} \quad e^{-\pi^{2} \text { Det } / L^{2}}=\frac{8}{\pi^{2}} \mathrm{e}^{-\mathrm{mt}} \text {------ (2) }
$$

Where,

$\mathrm{M}_{\mathrm{t}}=$ Moisture content at any time

$\mathrm{M}_{0}=$ Initial moisture content

$\mathrm{M}_{\mathrm{e}}=$ Equilibrium moisture content

$\mathrm{L}=$ Sample thickness

$\mathrm{T}=$ Time

$\mathrm{m}=\frac{\pi^{2} D_{e}}{L^{2}}=$ drying rate constant, $\mathrm{sec}^{-1}$

Consequently, a straight line should be obtained when plotting $\ln M R$ versus time $(\mathrm{t})$. The slope of the regression line is the drying rate constant, $m$ from which the effective diffusion co-efficient, $D_{e}$ is calculated.

The diffusion co-efficient, $\mathrm{D}_{\mathrm{e}}$ has an Arrhenius type of relationship with air-dry bulb temperature (abs). The relationship is as follows'

$\ln \mathrm{D}_{\mathrm{e}}=\ln \mathrm{D}_{\mathrm{o}}-\frac{E_{a}}{R T_{a b s}}$

Where, $D_{0}=$ the constant of integration and is usually referred to as a frequency factor when discussing Arrhenius equation; $\mathrm{E}_{\mathrm{a}}=$ activation energy of diffusion of water, cal $/ \mathrm{g}$-mole; $\mathrm{R}=$ gas constant, cal $/ \mathrm{g}-\mathrm{mole}^{\circ} \mathrm{K}$; and $\mathrm{T}_{\mathrm{abs}}=$ absolute temperature, ${ }^{\circ} \mathrm{K}$. 
From the semi-theoretical equation as shown in equation (2), symbolically ' $\mathrm{m}$ ' may represented as: $\mathrm{m}=$ $\mathrm{A}(\mathrm{L})^{-\mathrm{n}}$

or, $\operatorname{logm}=\log \mathrm{A}-\mathrm{nlog} \mathrm{L}$------(4)

Where, $\mathrm{A}=\pi^{2} \mathrm{D}_{\mathrm{e}}$ and $\mathrm{n}=2$

The above relationship shows that if external resistance to mass transfer is negligible and if simultaneous heat and mass transfer effects are taken into account, the value of the exponent of the power law equation should be 2 . But the above conditions are not always satisfied and experimentally determined ' $n$ ' value is found to be less than 2 as reported by co-author ${ }^{12}$.

\section{Results and discussions}

Experiment was conducted to determine the effects of loading density (mass/unit area) as well as thickness of aroids on drying rate at three different temperatures $\left(55^{\circ} \mathrm{C}, 60^{\circ} \mathrm{C}\right.$ and $\left.65^{\circ} \mathrm{C}\right)$ in a cabinet type of mechanical dryer. Experiment was also conducted to investigate the effect of air velocity on drying rate at constant temperature.

\section{Effect of loading density on drying time}

To determine the influence of loading density on drying time, $1.2 \mathrm{~kg} / \mathrm{m}^{2}$ and $2.4 \mathrm{~kg} / \mathrm{m}^{2}$ aroids slices were dried at different dry bulb temperature $\left(55^{\circ} \mathrm{C}\right.$, $60^{\circ} \mathrm{C}$ and $65^{\circ} \mathrm{C}$ ) at constant air velocity in a cabinet dryer. The drying rate constants were calculated by a regression analysis for each sample thickness using equation (2) and moisture ratio (MR) versus drying time (hr) were plotted on a semi-log scale (Fig.2) and rectangular scale (Fig.3).

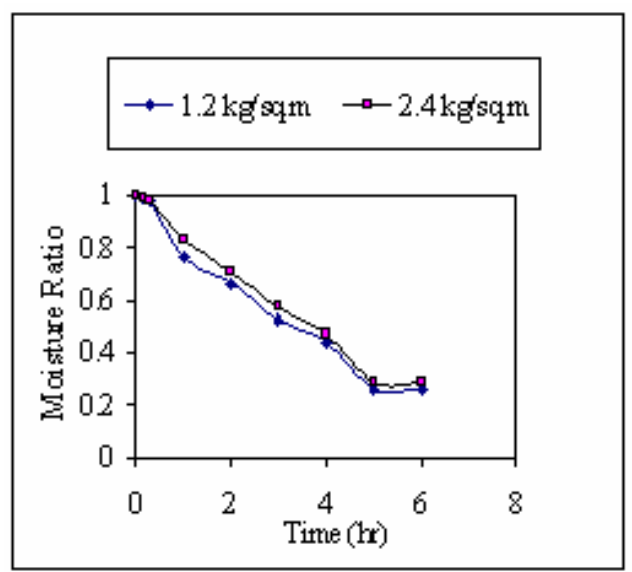

Fig 2. Effect of loading density on drying rate at $55^{\circ} \mathrm{C}$.

The following regression equations were developed:

$\mathrm{MR}=1.0289 \mathrm{e}^{-0.2384 \mathrm{t}}$ for $1.2 \mathrm{~kg} / \mathrm{m}^{2}$

$\mathrm{MR}=1.049 \mathrm{e}^{-0.223 \mathrm{t}} \quad$ for $2.4 \mathrm{~kg} / \mathrm{m}^{2}$
From Fig 2 and 3 it is seen that as loading density of aroids increases the rate of drying decreases, but drying rate constant does not decreases proportionately as loading density increases. Using $1.2 \mathrm{~kg} / \mathrm{m}^{2}$ loading density, the rate constant was $0.238 \mathrm{hr}^{-1}$ at $55^{\circ} \mathrm{C}$, whereas for twice the loading density at similar condition the rate constant was $0.223 \mathrm{hr}^{-1}$. This phenomenon can be advantageously used for increased dryer thoroughput. However, care should be taken not to increase loading density to such an extent that may increase drying time to a level at which the products are spoiled.

\section{Influence of thickness on drying rate}

To investigate the effect of thickness on drying behavior aroids slices were dried at constant air dry bulb temperature $\left(60^{\circ} \mathrm{C}\right)$ and constant air velocity $(0.6$ $\mathrm{m} / \mathrm{s}$ ). The results were analyzed by using equation (2) and are shown in Table-1. The equations developed are as follows:

$\mathrm{MR}=1.0026 \mathrm{e}^{-0.3987 \mathrm{t}}$ for $2 \mathrm{~mm}$ slice

$\mathrm{MR}=1.0397 \mathrm{e}^{-0.2567 \mathrm{t}}$ for $3 \mathrm{~mm}$ slice

$\mathrm{MR}=1.0842 \mathrm{e}^{-0.1521 \mathrm{t}}$ for $5 \mathrm{~mm}$ slice

By putting MR value $=0.13$ in the above equations, it is seen that for removal of $87 \%$ moisture $2 \mathrm{~mm}$ aroids slice takes only 5 hours whereas 3 and $5 \mathrm{~mm}$ aroids slices needed 8 and 14 hours respectively. So the products can be made shelf stable within these time.

From Fig. 3 and Table 1 it is also clear that thickness of the sample directly influences total drying time.

Table 1: Thickness dependence of drying rate constant of aroid slices

\begin{tabular}{cc}
\hline Thicknes (cm) & Drying rate constant $\left(\mathrm{sec}^{-1}\right)$ \\
\hline 0.2 & $1.10 \times 10^{-4}$ \\
0.3 & $7.13 \times 10^{-5}$ \\
0.5 & $4.22 \times 10^{-5}$
\end{tabular}

The relationship between drying rate constant (m) and sample thickness (L) was developed (Fig. 4) from the plot of drying rate constant versus sample thickness on log-log scale using equation (4). This relationship can be represented by a power law (regression) equation, which is as follows. $\mathrm{m}=0.9445 \mathrm{~L}^{-1.1451}$ 


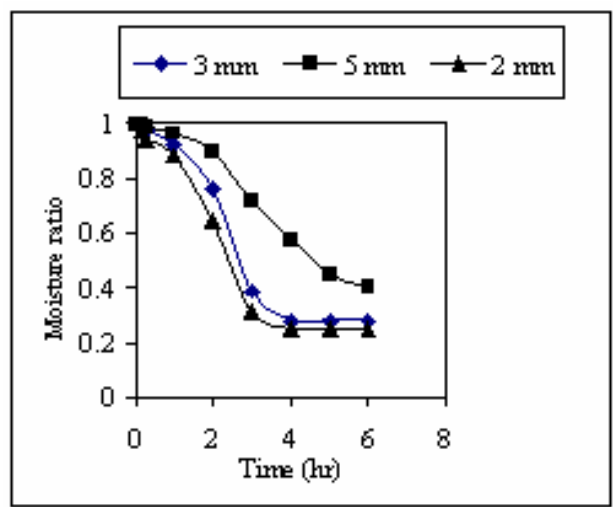

Fig 3. Effect of thickness on drying behavior of aroid slices at $60^{\circ} \mathrm{C}$.

From the above equation, it is seen that the value of index ' $n$ ' of the power law equations is 1.14 at $60^{\circ} \mathrm{C}$. This value is lower than 2 as predicated by equation (4) and it indicates that the external resistance to mass transfer is highly significant under the given conditions. This also indicates that higher airflow rates will give higher drying rates. Islam ${ }^{12}$ showed an ' $n$ ' value of 1.70 while drying potato using higher airflow rates $(2.5$ $\mathrm{m} / \mathrm{s}$ ). The above discrepancy of ' $\mathrm{n}$ ' values is primarily due to airflow rate and sample thickness, and shows the relative importance of external or internal mass transfer resistance. However, product structure and composition and simultaneous heat and mass transfer effects also play an important role in this regard. Islam ${ }^{12}$ while working with potato, showed that by taking into account of the simultaneous heat and mass transfer effect value of ' $n$ ' could be corrected to 2 from 1.7.

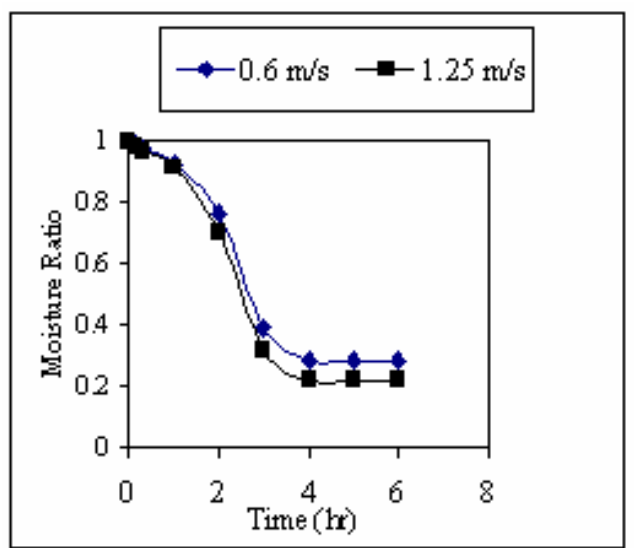

Fig 4. Influence of air velocity on drying rate at $60^{\circ} \mathrm{C}$ for $3 \mathrm{~mm}$ slice.

\section{Influence of air velocity on drying time}

From Fig. 5 and 6 it is obvious that when air velocity is increased, drying rate constant is also increased, as higher air velocity reduces the external resistance to mass transfer. The decrease in external resistance leads drying to be controlled by increasing internal resistance to mass transfer as is important for analyzing drying data according to Fick's diffusion equation. However, doubling the air velocity did not increase the rate constant twice as much. Moreover, for certain drying conditions, there may be a fixed air velocity above which increase in velocity will not result in increased drying rate ${ }^{12}$.

\section{Influence of temperature on drying time}

From Fig 7 it is seen that the moisture ratio (MR) decreases with time and time to dry to a specific moisture ratio decreases with increasing temperature. Thus higher temperature would give faster drying rate. At very high temperature and low humidity drying rate may initially increase, but as drying progresses resultant case hardening would reduce drying rate drastically and deteriorate the quality of the product due to cooking instead of drying. High temperature also may scorch the product and thus selection of optimum temperature for drying is of significance during drying particularly, mechanical drying with counter current operation ${ }^{13,15}$.

From the drying rate constants determined by regression analysis, the diffusion co-efficients were determined. Diffusion co-efficient $\left(D_{\mathrm{e}}\right)$ versus inverse absolute temperature $\left(\mathrm{T}_{\mathrm{abs}}{ }^{-1}\right)$ was plotted on a semi-log co-ordinate and regression lines were drawn. From the slope of the resultant straight line (Fig. 8), activation energy $\left(E_{a}\right)$ for diffusion of water was calculated and found to be $5.12 \mathrm{Kcal} / \mathrm{g}$-mole.

The calculated activation energy is lower than 12.5 $\mathrm{Kcal} / \mathrm{g}$-mole of activation energy for diffusion of water from potato by Saravacos and Charm ${ }^{18}$, those found by Afzal Babu et al. ${ }^{1}$ for onion $(26.83 \mathrm{Kcal} / \mathrm{g}$ mole) and for cucumber (8.50 Kcal/g-mole), and cauliflower $\left(7.76 \mathrm{Kcal} / \mathrm{g}\right.$-mole) found by $\mathrm{Iqbal}^{10}$ but higher than that found for mango $(4.4 \mathrm{Kcal} / \mathrm{g}$-mole) by Islam et al. ${ }^{11}$.That means the activation energy value is within the range of values reported by many researcher. The differences in activation energy may arise from differences in product characteristics as well as process parameters.

The dependence of diffusion coefficient on absolute temperature can be represented as

$\mathrm{D}_{\mathrm{e}}=0.0015 \mathrm{e}^{-2574.3} \mathrm{~T}_{\mathrm{abs}}{ }^{-1}$

Where,

$\mathrm{D}_{\mathrm{e}}=$ Diffusion coefficient $\left(\mathrm{cm}^{2} / \mathrm{s}\right)$ and

$\mathrm{T}_{\mathrm{abs}}=$ Absolute temperature $\left({ }^{\circ} \mathrm{K}\right)$ 
Table 2: Influence of temperature on diffusion coefficient

\begin{tabular}{cc}
\hline $\begin{array}{c}\text { Temperature } \\
\left({ }^{\mathbf{O}} \mathbf{C}\right)\end{array}$ & $\begin{array}{c}\text { Diffusion coefficient } \\
\left(\mathbf{~ c m}^{2} / \mathbf{s}\right)\end{array}$ \\
\hline 55 & $4.43 \times 10^{-7}$ \\
60 & $6.50 \times 10^{-7}$ \\
65 & $1.07 \times 10^{-6}$
\end{tabular}

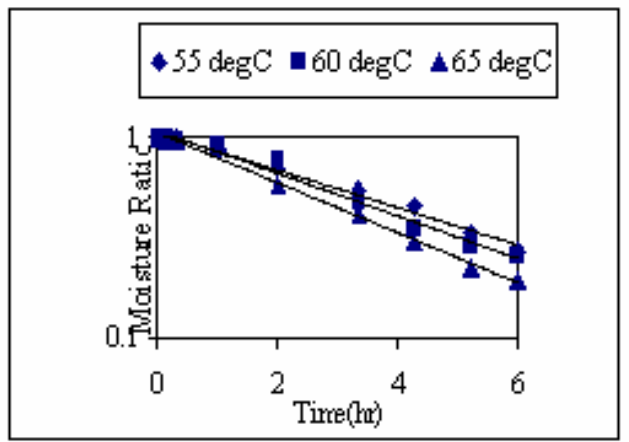

Fig.5: Effect of temperature on drying rate at constant loading density $\left(1.2 \mathrm{~kg} / \mathrm{m}^{3}\right)$

\section{Comparison of composition of fresh and dried aroids}

The fresh aroids contained $91.2 \%$ moisture, $0.38 \%$ protein, $0.22 \%$ fat, $1.24 \%$ ash and $6.96 \%$ carbohydrate where as the mechanical dried aroids contained $11.4 \%$ moisture, $2.52 \%$ protein, $0.09 \%$ fat, $7.86 \%$ ash and $78.13 \%$ carbohydrate (Table 3 ). During drying most of the water in the aroids are vaporized so the moisture content is so less and consequently solid content increased. This increased solid content results in the increased protein, ash, and carbohydrate content. The fat content decreased in the dried sample, which may be due to the oxidation of fat during drying.

Table 3: Comparison of composition of fresh and dried aroids

\begin{tabular}{|c|c|c|}
\hline Parameters & $\begin{array}{c}\text { Fresh aroids } \\
(\%)\end{array}$ & $\begin{array}{c}\text { Dried aroids } \\
(\%)\end{array}$ \\
\hline Moisture & 91.2 & 11.4 \\
\hline Protein & 0.38 & 2.52 \\
\hline Fat & 0.22 & 0.09 \\
\hline Ash & 1.24 & 7.86 \\
\hline $\begin{array}{c}\text { Total } \\
\text { carbohydrate }\end{array}$ & 6.96 & 78.13 \\
\hline
\end{tabular}

\section{Development of product}

The dried aroids were grinded in a laboratory grinder and aroids powder was obtained. Then "chapatti" was prepared by mixing wheat flour and aroids powder at different ratio. The products are then tested organoleptically.

\section{Sensory evaluation of developed product}

The consumer's acceptability of developed products was evaluated by a taste testing panel. The 1-9 hedonic rating test was used to determine this acceptability. A two way analysis of variance (ANOVA) was carried for color, flavour, texture and overall acceptability preference of developed product and the results are shown in Table 2.

As shown in Table 2 (DMRT) the sample 1 was the most acceptable product securing the highest score 7.3 (out of 9) among the samples and ranked as "like moderately". However, sample 2 and 3 were equally acceptable at $5 \%$ level of statistical significance securing score 6.2 and 5.5 respectively and ranked as "like slightly". But sample 4 secured the lowest score (4.8) and was ranked as "neither like nor dislike".

Table 2. Mean score for color, flavor, texture and overall acceptability of "chapatti"

\begin{tabular}{|c|c|c|c|c|}
\hline \multirow[b]{2}{*}{$\begin{array}{l}\text { Sam- } \\
\text { ple }\end{array}$} & \multicolumn{4}{|c|}{ Sensory attributes } \\
\hline & Color & Flavor & Texture & $\begin{array}{c}\text { Overall } \\
\text { Acceptability }\end{array}$ \\
\hline 1 & $7.0^{\mathrm{a}}$ & $6.3^{\mathrm{b}}$ & $7.1^{\mathrm{a}}$ & $7.3^{\mathrm{a}}$ \\
\hline 2 & $6.1^{\mathrm{b}}$ & $7.6^{\mathrm{a}}$ & $5.8^{\mathrm{b}}$ & $6.2^{\mathrm{b}}$ \\
\hline 3 & $5.6^{\mathrm{bc}}$ & $5.3^{\mathrm{c}}$ & $5.1^{\mathrm{b}}$ & $5.5^{\mathrm{bc}}$ \\
\hline 4 & $5.1^{\mathrm{c}}$ & $4.4^{\mathrm{d}}$ & $4.3^{\mathrm{c}}$ & $4.8^{\mathrm{c}}$ \\
\hline
\end{tabular}

Sample 1: Aroids powder: wheat flour $=1: 4$ Sample 2: Aroids powder: wheat flour $=1: 3$ Sample 3: Aroids powder: wheat flour $=1: 2$ Sample 4: Aroids powder: wheat flour $=1: 1$

\section{Conclusions}

This study demonstrated that the aroids flour could be conveniently incorporated into wheat flour for the production of "chapatti" in order to produce "chapatti" of acceptable quality. Hedonic rating test for organoleptic quality indicated that $20 \%$ of aroids flour could be added in the production of "chapatti" to maintain acceptable scores for color, flavour and texture of the product. Every year a substantial amount of aroids are cultivated in Bangladesh. The study showed that there is a good prospect of processing of aroids through diversified and valueadded products. By processing aroids its market value may be increased and production can be maximized. Therefore, it may be concluded that, aroids can be successfully and economically preserved during its peak season by drying process. 
Mechanical drying systems may be used for large-scale production.

\section{References}

1. Afzal Babu, S. M. M., Kowser Sarker, M. A. S. and Islam, M. N. Kinetics of mechanical, Solar and Sun drying of onion. Bangladesh J. Agril. Engg. 8 (1\&2): 49-61, 1997.

2. AOAC methods. Officials Methods of Analysis $12^{\text {th }}$ edition. Association of Official Agricultural Chemists, Washington D.C. USA, 1984.

3. Brooker, D. B., Bakker, F.W. and Hall, C.W. Drying cereal grains: Theory and simulation of cereal grain drying. The AVI Pub. Co. Inc. USA. 185(1974).

4. Bradbury, D.H. and Holloway, W.D. 1988. Chemistry of tropical root crops. ACIAR, Canberra (1988).

5. Chowdhury, B. The nutritive value of edible aroids grown in Bangladesh. M.S. Thesis. Dept. of Biochemistry, Bangladesh Agricultural University. Mymensingh (1975)

6. Coursey, D. G. The edible aroids. World Crops. 20: (4), 25-30(1968).

7. Gerpacio, A. L., Roxas, D B., Ulchanco, H. M., Roxas, N. P., Custudio, C. C., Marcado, C., Gloria, L. A., and Castillo, L. S. Tuber meals as carbohydrate sources in broiler rations. TPI conf. Proc. Animal Fees of Trop. \& Subtrop. Region. 151-154 (1974).

8. Greenwell, A. B. H. Taro with special reference to its culture and uses in Hawaii. Econ. Bot. 1: (3), 276289 (1947).
9. Heldman, D. R. Food Process Engineering. AVI Pub. Co. Inc. Westport. Connecticut. U.S.A (1974).

10. Iqbal, A. Processing and preservation of cauliflower and cucumber by dehydration and fermentation. M.S. Thesis. Dept. of Food Technology and Rural Industries, Bangladesh Agricultural University. Mymensingh (2003).

11. Islam, M.N., Uddin, M.B. and Islam, N.M. Development of shelf-stable dehydration mango products. Bangladesh j. of Agril. Engg. 4:(1\&2), 6573 (1997).

12. Islam, M. N.Use of solar energy for development of shelf-stable potato product. Ph.D. Thesis. Royal Veterinary and Agricultural University, Copenhagen, Denmark (1980).

13. Karel, M., Fennema, O.R. and Lund, D.B. Principles of Food Science, Part-II, Physical Principles of Food Preservation. Marcel Deker, Inc.New York and Basel (1975).

14. Kay, D. E.. Crop and product digest No. 2: Root crops. 2nd Edition. London: Tropical Development and Research Institute. 380 (1987)

15. Potter, N.N. Food Science, CBs Publishers and Distributors, Shahdara, Delhi. 78(1978).

16. Rashid, M.M. Transferable Techniques in tuber crops. Tuber crop research centre, BARI. Joydebpur, Gazipur. 14(1991).

17. Rangarna, S. Handbook of Analysis of Fruit and Vegetable Products. Tata McGrow Hill Cl. Ltd. 1-30. New Delhi. India (1992).

18. Saravacos, G. D. and Charm, S. E. A study of the mechanism of fruits and vegetable dehydration. Journal of Food Technology.16: 78(1962). 